\title{
RECREATIONAL PHYSICAL ACTIVITY AND THE PROBLEM OF PARTICULATE MATTER AIR POLLUTION
}

\author{
REKREACYJNA AKTYWNOŚĆ FIZYCZNA A PROBLEM \\ ZANIECZYSZCZENIA POWIETRZA PYŁEM ZAWIESZONYM
}

\author{
Medical University of Silesia in Katowice \\ Department of Epidemiology, School of Medicine in Katowice \\ Śląski Uniwersytet Medyczny w Katowicach \\ Katedra i Zakład Epidemiologii Wydziału Lekarskiego w Katowicach
}

\begin{abstract}
Studies reveal the negative impact of exposure to particulate air pollution on human health, especially on respiratory and circulatory systems. At the same time the beneficial effects of maintaining adequate level of physical activity are well known. In this review author presents analysis of chosen current articles about health effects of recreational physical activity in the environment of high level of ambient particulate matter air pollution. Available data suggests that there are complex relations between physical activity and exposure to air pollution. The direct positive effects of recreational physical activity include decrease of diastolic blood pressure and bronchial dilatation. It is proven that particulate air pollution show contrary impact on respiratory and cardiovascular systems. The mechanisms of this influence consist of induction of inflammation in respiratory epithelial cells, increase of oxidative stress and alterations in autonomic nervous system regulation. Changes induced by air pollution, expressed by the decrease of spirometry parameters (most commonly $\mathrm{FEV}_{1}$ decrease) were observed even in young and healthy adults doing recreational physical activity. Nevertheless, several studies suggest modulatory impact of physical exercises, which may limit the pro-inflammatory influence of particulate air pollution. Less expressed short-term negative effects of exposure have been observed in people doing physical exercise in comparison to those being inactive at the same time. In addition, apart from direct health effects, air pollution may also discourage exposed people from doing physical activity. Therefore, balanced choices regarding physical activity are needed, in order to decrease the negative impact of exposure to air pollution, without limiting the positive impact of physical activity. Still, new research is needed in order to fully explain relations between physical activity and exposure to air pollution. This will allow to elaborate physical activity guidelines including current air pollution level, better risk communication and promotion of safe ways of exercise.
\end{abstract}

Key words: air pollution, particulate matter, physical activity, recreation

\section{STRESZCZENIE}

Wyniki badań wskazują, że narażenie ludzi na zanieczyszczenia powietrza pyłem zawieszonym wiąże się z negatywnymi skutkami zdrowotnymi, oddziałując szczególnie negatywnie na funkcję układu oddechowego i krążenia. Zarazem powszechnie znane są pozytywne efekty utrzymywania właściwego poziomu aktywności fizycznej. W pracy przedstawiono analizę wybranych aktualnych artykułów dotyczących efektów zdrowotnych i aktualnych zaleceń dotyczących rekreacyjnej aktywności fizycznej w warunkach narażenia na zanieczyszczenie powietrza pyłem. Dostępne dane wskazują na występowanie złożonych zależności pomiędzy wysiłkiem fizycznym i narażeniem na zanieczyszczenia powietrza. Do bezpośrednich pozytywnych efektów rekreacyjnej aktywności fizycznej należą zmniejszenie ciśnienia rozkurczowego krwi i rozszerzenie oskrzeli. Zanieczyszczenie powietrza pyłem zawieszonym wykazuje oddziaływanie przeciwstawnie do wysiłku fizycznego w zakresie

(C) National Institute of Public Health - National Institute of Hygiene / Narodowy Instytut Zdrowia Publicznego - Państwowy Zakład Higieny 
funkcjonowania układu oddechowego i krążenia. Mechanizmy tego oddziaływania obejmują indukcję stanu zapalnego w komórkach nabłonka dróg oddechowych, zwiększanie stresu oksydacyjnego i zaburzanie funkcji układu nerwowego autonomicznego. Zmiany indukowane przez zanieczyszczenia powietrza, wyrażone między innymi przez pogorszenie parametrów spirometrycznych (najczęściej zmniejszenie $F_{E V}$ ) i wzrost ciśnienia tętniczego krwi, obserwowane były już u zdrowych osób dorosłych, uprawiających rekreacyjną aktywność fizyczną. Wyniki niektórych badań wskazują jednak na modulujący wpływ ćwiczeń fizycznych, który może powodować ograniczenie prozapalnego oddziaływania zanieczyszczeń powietrza. Zaobserwowano słabiej wyrażone negatywne krótkoterminowe efekty narażenia na pył zawieszony u osób uprawiających ćwiczenia fizyczne w czasie narażenia, w porównaniu do osób, które w tym czasie nie ćwiczyły. Poza bezpośrednim powodowaniem negatywnych skutków zdrowotnych, zanieczyszczenie powietrza może również przyczyniać się do rezygnacji z podejmowania aktywności fizycznej przez osoby narażone. $Z$ tego powodu niezbędne jest wypośrodkowanie wyborów dotyczących aktywności fizycznej, w celu zmniejszenia negatywnych skutków narażenia, bez ograniczania pozytywnych oddziaływań aktywności fizycznej. Konieczne są dalsze badania zmierzające do wyjaśnienia skomplikowanych relacji pomiędzy wysiłkiem fizycznym a narażeniem na zanieczyszczenia powietrza. Pozwoli to na wypracowanie rekomendacji odnośnie aktywności fizycznej uwzględniających aktualny poziom zanieczyszczenia powietrza, właściwą ocenę ryzyka i promowanie bezpiecznych form ćwiczeń.

Slowa kluczowe: zanieczyszczenie powietrza, pył zawieszony, aktywność fizyczna, rekreacja

\section{INTRODUCTION}

Human exposure to particulate matter air pollution is related to negative health effects. It affects especially respiratory and cardiovascular systems and increases the risk of chronic lung diseases exacerbation, acute coronary events, heart arrhythmia or stroke (1). Qualitative and quantitative composition of air pollution shows seasonal variations, depending on atmospheric conditions and human activity (2). In Poland particulate matter air pollution with particles of an aerodynamic diameter below $10 \mu \mathrm{m}\left(\mathrm{PM}_{10}\right)$ is a main problem in winter season, when its major source of emission is burning fuels for heating (2-4). Fine particulate matter is particularly dangerous for the function of respiratory and cardiovascular system $(1,5)$. The highest risk of negative changes is assigned to particulate matter of aerodynamic diameter of particles below $2.5 \mu \mathrm{m}$ $\left(\mathrm{PM}_{2,5}\right)$ due to its smaller size which enables deeper penetration into respiratory tract and the possibility of migration to the bloodstream (5-6).

Long-term exposure to particulate air pollution increases the risk of exacerbations of chronic diseases like asthma and chronic obstructive pulmonary disease. It increases also the risk of developing lung neoplasm (1). Current data indicates that the adverse health consequences of exposure to air pollution are highest in children, elderly and people suffering from respiratory or cardiovascular disease (5).

In healthy people the risk of developing negative health effects of air pollution is determined predominantly by the level of exposure (air pollutants concentrations in ambient air) and its duration. If personal susceptibility is not taken into account, the main role of absorbed dose should be considered. In this situa-

\section{WSTĘP}

Narażenie ludzi na zanieczyszczenia powietrza pyłem zawieszonym wiąże się z negatywnymi skutkami zdrowotnymi. Oddziałując szczególnie negatywnie na stan układu oddechowego i krążenia, zwiększając ryzyko zaostrzenia przewlekłych chorób płuc, wystąpienia zawałów mięśnia sercowego, zaburzeń rytmu serca, czy udarów mózgu (1). Skład jakościowy i ilościowy zanieczyszczeń powietrza wykazuje zmienność sezonową, związaną z warunkami atmosferycznymi i działalnością człowieka (2). W Polsce zanieczyszczenie pyłem zawieszonym o średnicy aerodynamicznej cząstek poniżej $10 \mu \mathrm{m}\left(\mathrm{PM}_{10}\right)$ stanowi największy problem w okresie zimowym, kiedy jego źródłem są przede wszystkim procesy spalania w celu ogrzewania pomieszczeń (tzw. niska emisja) (2-4). Szczególnie niebezpieczne dla funkcjonowania układu oddechowego i układu krążenia jest narażenie na drobny pył zawieszony w powietrzu $(1,5)$. Największe ryzyko wystąpienia niekorzystnych zmian przypisywane jest drobnemu pyłowi frakcji $\mathrm{PM}_{2,5}$, o średnicy aerodynamicznej cząsteczek poniżej 2,5 $\mu \mathrm{m}$, ze względu na mniejszy rozmiar umożliwiający głębszą penetrację do układu oddechowego, a także możliwość migracji do układu krążenia (5-6).

Długoterminowe narażenie na zanieczyszczenia pyłowe skutkuje zwiększeniem ryzyka zaostrzeń chorób przewlekłych, takich jak astma oskrzelowa i przewlekła obturacyjna choroba płuc. Zwiększa również ryzyko zachorowania na nowotwory płuc (1). Aktualny stan wiedzy wskazuje, że największe konsekwencje zdrowotne w związku z narażeniem na zanieczyszczenia powietrza dotyczą dzieci, osób starszych oraz osób obciążonych przewlekłymi chorobami płuc i układu krążenia (5). 
tion, apart from level and duration of exposure, respiratory minute volume, which depends on current physical activity, plays significant role. This aspect is important when we consider active recreation. Recreational physical activity is a popular way of spending leisure time, which is especially recommended, due to commonly known positive effects of physical activity. Regular exercise decreases the risk of developing among others arterial hypertension, ischemic heart disease, stroke or diabetes mellitus (7). Direct positive effects of physical activity on the function of respiratory and cardiovascular systems consist of bronchodilatation and blood pressure decrease (8-9). Popular types of active recreation like jogging or cycling frequently can take place in the conditions of increased levels of air pollutants. In such environment physical activity, depending on its intensity, leads to increase in the absorbed dose of pollutants.

Observations indicate that even short-term exposure to air pollution during increased physical activity may result in subclinical functional changes in respiratory system of young and healthy adults (10). These changes are expressed in decrease in respiratory function. Such effect requires attention as young and healthy adults more frequently participate in recreational physical activity (jogging, cycling, etc.). Scientific evidence on this issue is relatively limited, although this aspect is important for public health

AIM. According to this fact, author conducted literature review in order to analyse chosen data on health effects of recreational physical activity in the conditions of exposure to particulate air pollution and to present published recommendations on this topic.

For the purpose of the study, author reviewed literature from years 2006-2018 recorded in PubMed and Polska Bibliografia Lekarska databases. Key words: 'air pollution', 'health effects', 'particulate matter', 'physical activity' and their combinations were used. In total, 245 articles were identified and 47 concerning relations between particulate air pollution and physical activity were chosen.

\section{PATHOMECHANISM OF AIR POLLUTION IMPACT ON HEALTH}

Pathomechanism of air pollution impact on human health is complex. In case of fine particulate matter it consists of, among others, increase of oxidative stress, induction of airways inflammation and autonomic nervous system dysregulation, expressed for example in decreased physiological heart rate variability. Direct penetration of smallest particles to bloodstream is also important. Endothelium dysfunction and vasoconstriction are among observed effects of this process $(6,11$ 12).
U osób zdrowych poziom ryzyka wystąpienia zdrowotnych skutków narażenia na zanieczyszczenia powietrza jest przede wszystkim kształtowany przez poziom narażenia (stężenie zanieczyszczeń w powietrzu) i czas jego trwania. Pominąwszy rozważania dotyczące roli podatności osobniczej dominujące znaczenie ma wielkość dawki pochłoniętej. Poza poziomem i czasem trwania narażenia, znaczenie posiada wielkość wentylacji minutowej płuc, zależna w istotnym stopniu od aktualnej aktywności fizycznej. Ten aspekt ma istotne znaczenie, gdy bierze się pod uwagę aktywną rekreację. Rekreacyjna aktywność fizyczna stanowi popularny sposób spędzania wolnego czasu, szczególnie polecany w świetle powszechnie znanych pozytywnych efektów wysiłku fizycznego. Regularny wysiłek przyczynia się między innymi do zmniejszenia ryzyka zachorowania na nadciśnienie tętnicze, chorobę niedokrwienną serca, udar mózgu, czy cukrzycę (7). Bezpośrednie pozytywne oddziaływania wysiłku fizycznego na funkcjonowanie układu oddechowego i krążenia obejmują natomiast rozszerzenie oskrzeli i zmniejszenie ciśnienia tętniczego krwi (8-9). Popularne formy rekreacyjnej aktywności fizycznej takie jak bieganie, czy jazda na rowerze często mogą mieć miejsce $\mathrm{w}$ warunkach narażenia na zanieczyszczenia powietrza atmosferycznego. W warunkach takich, zależnie od swojej intensywności, wysiłek prowadzi do zwiększenia pochłoniętej dawki zanieczyszczeń.

Istnieją obserwacje wskazujące, że nawet krótkotrwałe narażenie na zanieczyszczenia powietrza w czasie zwiększonej aktywności fizycznej może skutkować subklinicznymi zmanami czynnościowymi u młodych i zdrowych osób dorosłych. Zmiany te wyrażone są poprzez pogorszenie sprawności wentylacyjnej płuc (10). Ten efekt zasługuje tym bardziej na uwagę, że młode osoby dorosłe częściej angażują się w rekreacyjną aktywność fizyczną (swobodny bieg, jazda na rowerze, itp.). Omawiany aspekt, jakkolwiek ważki z punktu widzenia zdrowia publicznego, w tym zadań profilaktycznych, posiada stosunkowo nieliczną dokumentację naukową.

CEL. W związku z tym prześledzono literaturę przedmiotu $\mathrm{w}$ celu przeprowadzenia analizy wybranych danych dotyczących oddziaływań zdrowotnych rekreacyjnej aktywności fizycznej w warunkach narażenia na zanieczyszczenie powietrza pyłem zawieszonym oraz opublikowanych rekomendacji w tym zakresie.

Zgodnie ze sformułowanym powyżej celem pracy prześledzono piśmiennictwo z lat 2006-2018, odnotowane w anglojęzycznej bazie „PubMed” oraz Polskiej Bibliografii Lekarskiej. Wykorzystano następujące słowa kluczowe: ,air pollution”, ,health effects”, ,,particulate matter", ,physical activity” oraz ich kombinacje. W sumie zidentyfikowano 245 artykułów i wybrano 47 prac dotyczących relacji pomiędzy zanieczyszczeniem powietrza pyłem a aktywnością fizyczną. 
Results of an interesting study conducted in China underline the proinflammatory mechanism of air pollution impact on the airways of healthy people (13). During the 2008 Olympics in Beijing, due to radical actions, air pollutants concentrations substantially decreased. The study documented significant decrease in several biomarkers of systemic and airways inflammation, hemosthasis, heart rate and systolic blood pressure during the Olympics. Later observations revealed that the same biomarkers increased again after the end of Olympics, when the air quality deteriorated. Fractioned exhaled nitric oxide (FeNO) is considered a simple and useful biomarker of airways inflammation (14). Its increase, related to exposure to particulate matter, was observed among others in studies conducted in healthy adult volunteers (15) and in healthy school children (16). Other study, that took into consideration chemical composition of $\mathrm{PM}_{2,5}$, revealed that FeNO increase showed the strongest correlation with the concentration of organic and elemental carbon (organic carbon - OC, elemental carbon - EC), NO3(-), and $\mathrm{NH} 4(+)$. Researchers observed that the increase in these chemical substances concentrations resulted in the decrease in the methylation of nitric oxide synthase 2 gene (NOS2) in human epithelial cells. As a result, the production of NO increased. This effect was the strongest after short-term exposure within $24 \mathrm{~h}$ before the measurements (17). It is worth mentioning, that the chemical composition of $\mathrm{PM}_{2,5}$ particulate matter is complex and this aspect is ignored in many studies. Particulate air pollution impact on human health may depend not only on the concentration of particulate matter as a whole, but also on the concentrations of different chemical constituents. Cao et al. analysed the impact of $\mathrm{PM}_{2,5}$ level on cardiovascular mortality (18). They observed that more important than the concentration of particulate matter were the concentrations of its chemical constituents. Greater risk was related to increased levels of substances which originate from fossil fuels burning, like $\mathrm{EC}, \mathrm{OC}, \mathrm{NH} 4(+), \mathrm{NO} 3(-), \mathrm{Cl}(-)$.

By aforementioned mechanisms, exposure to particulate matter air pollution, especially with fraction $\mathrm{PM}_{2,5}$, may increase systolic and diastolic blood pressure, impair nocturnal blood pressure decrease and cause deterioration of spirometry parameters, also in adolescents and young adults (19-22). This is particularly important in case of those participating in intense physical activity like running or cycling. It was proven that through intensive breathing effort during increased physical activity the number of particles deposed in pulmonary alveoli is 10 times higher than the number accumulated during sleep (23). Intensive exercises cause domination of mouth ventilation and may impair mechanisms of mucociliary clearance in the airways (11).

\section{PATOMECHANIZM ODDZIAŁYWANIA ZANIECZYSZCZEŃ POWIETRZA}

Patomechanizm oddziaływań zanieczyszczeń powietrza na zdrowie człowieka jest złożony. W przypadku drobnego pyłu obejmuje on między innymi zwiększenie stresu oksydacyjnego, indukcję procesu zapalnego w drogach oddechowych oraz zaburzanie regulacji układu autonomicznego, co wyrażone jest między innymi zmniejszoną fizjologiczną zmiennością rytmu serca. Istotna jest także bezpośrednia penetracja najdrobniejszych frakcji pyłu do krwiobiegu, a udokumentowane efekty tego procesu obejmują $\mathrm{m}$. in. dysfunkcję śródbłonka i skurcz naczyń $(6,11-12)$.

$\mathrm{Na}$ mechanizm prozapalnego oddziaływania zanieczyszczeń powietrza na drogi oddechowe u zdrowych osób wskazują wyniki interesującego badania prowadzonego w Chinach w trakcie Igrzysk Olimpijskich w Pekinie w 2008 roku, kiedy poprzez zdecydowane działania znacząco zredukowano stężenia zanieczyszczeń powietrza (13). Przeprowadzone obserwacje udokumentowały istotne zmniejszenie stężeń biomarkerów układowego i oddechowego stanu zapalnego, stresu oksydacyjnego, hemostazy, częstości akcji serca i ciśnienia skurczowego w trakcie trwania Olimpiady oraz ich ponowne zwiększenie po jej zakończeniu, kiedy ponownie pogorszeniu uległa jakość powietrza. Wskaźnikiem uważanym za przydatny i prosty marker zapalenia $w$ drogach oddechowych jest tlenek azotu w powietrzu wydychanym (FeNO) (14). Wzrost jego stężenia w odpowiedzi na narażenie na pył zawieszony wykazano między innymi w badaniach prowadzonych na zdrowych ochotnikach dorosłych (15) oraz wśród zdrowych dzieci szkolnych (16). W innym badaniu biorącym pod uwagę skład chemiczny pyłu $\mathrm{PM}_{2,5}$ zaobserwowano, że zwiększenie FeNO najlepiej korelowało ze stężeniem węgla organicznego i elementarnego (organic carbon - OC, elemental carbon - EC), NO3(-) i NH4(+). Jak wykazano, wzrost stężenia tych substancji powoduje zmniejszenie metylacji genu syntazy tlenku azotu 2 (NOS2) w komórkach ludzkiego nabłonka, a przez to zwiększoną produkcję NO, z efektem najsilniej wyrażonym dla krótkotrwałego narażenia w ciągu 24h poprzedzających pomiar (17). Warto zauważyć, że pod względem chemicznym pył $\mathrm{PM}_{2,5}$ ma bardzo złożony skład, a aspekt ten jest w wielu badaniach pomijany. Oddziaływanie pyłu na zdrowie człowieka może być związane nie tylko ze stężeniem samego pyłu, lecz również ze stężeniem poszczególnych substancji chemicznych. Cao $i$ wsp. analizując wpływ stężenia $\mathrm{PM}_{2,5}$ na umieralność z przyczyn sercowo-naczyniowych zaobserwowali, że ważniejsze od ogólnego stężenia pyłu było stężenie składających się nań substancji chemicznych. Większe ryzyko wiązało się ze wzrostem stężenia substancji pochodzących ze spalania paliw kopalnych, jak EC, OC, NH4(+), $\mathrm{NO} 3(-), \mathrm{Cl}(-)(18)$. 


\section{PHYSICAL ACTIVITY AND AIR POLLUTION - OBSERVATIONS IN HUMAN}

Results of studies conducted in healthy adults indicate that short-term exposure to air pollution during physical exercise leads to temporary deterioration in lung function. In addition, it was shown that exercises done in conditions of increased air pollution have worse metabolic efficiency, expressed in decreased maximal oxygen consumption and increased blood lactate levels (24-25). In terms of respiratory function, decrease in forced expiratory volume in 1 second $\left(\mathrm{FEV}_{1}\right)$ is among frequently noted changes. Rundell et al. showed statistically significant decrease in $\mathrm{FEV}_{1}$ after 30-minutes of intensive exercise, namely fast running, in the conditions of increased $\mathrm{PM}_{1}$ (26). Similar effects were observed in conditions of experimental exposure to Diesel exhaust (27). What is important, analogous to that were changes observed after exposure to second-hand smoke prior to exercise - after maximum exercise $\mathrm{FEV}_{1}$ decreased and inflammatory cytokines levels (TNF- $\alpha$ i IFN- $\gamma$ ) increased in comparison to the control group (28). Negative impact of particulate air pollution on the spirometry results was also observed in the experiment conducted in the group of healthy volunteers in Barcelona. The study consisted of four different exposure scenarios -2 hours physical exercise or rest in places of low and high level of traffic. Researchers showed that each interquartile range increase in $\mathrm{PM}_{2,5}$ was related to significant decrease in $\mathrm{FEV}_{1}$ and forced vital capacity (FVC). At the same time, the study design enabled to show that physical exercise was related to significant increase in spirometry parameters like $\mathrm{FEV}_{1}$, Tiffeneau index $\left(\mathrm{FEV}_{1} / \mathrm{FVC}\right)$ and maximal midexpiratory flow $\left(\mathrm{MEF}_{25-75}\right)$. This positive effect was lower, but still present, when exercises took place in condition of exposure to higher levels of $\mathrm{PM}_{2.5}(8)$. This observation underlines the complexity of the relationship between the air pollution level and the exercise intensity in relation to the biological response of organism. Results of studies that analyse long-term effects also indicate the possibility of limiting the negative impact of air pollution by the physical activity. Laeremans et al. analysed the impact of weekly physical activity of volunteers and their weekly exposure to particulate air pollution on the results of spirometry, which was performed at the beginning and the end of each study week (29). Authors observed decrease in the lung function expressed in spirometry parameters $\left(\mathrm{FEV}_{1}, \mathrm{FEV}_{1} / \mathrm{FVC}, \mathrm{MEF}_{25-75}\right)$ in response to the exposure to air pollution. However, when the level of carbon air pollution was low $\left(<1 \mu \mathrm{g} / \mathrm{m}^{3}\right)$, there was a trend towards improvement of lung function with each increase in weekly physical activity of 1 metabolic equivalent per hour (MET/h).
Poprzez wymienione patomechanizmy narażenie na zanieczyszczenia powietrza pyłem, szczególnie frakcji $\mathrm{PM}_{2,5}$, prowadzić może do wzrostu skurczowego i rozkurczowego ciśnienia krwi, zmniejszenia nocnego fizjologicznego spadku ciśnienia oraz pogorszenia parametrów spirometrycznych, również u młodzieży i młodych osób dorosłych (19-22). Jest to szczególnie istotne w odniesieniu do osób podejmujących wzmożoną aktywność fizyczną, jak bieganie lub jazda na rowerze. Wykazano, że podczas nasilonego wysiłku oddechowego w związku z intensywną aktywnością fizyczną 10-krotnie wzrasta depozycja cząstek pyłu w pęcherzykach płucnych w porównaniu do ilości akumulowanej podczas snu (23). Intensywny wysiłek związany jest $\mathrm{z}$ dominacją oddychania przez usta, może również prowadzić do upośledzenia mechanizmów oczyszczania śluzowo-rzęskowego dróg oddechowych (11).

\section{WYSIŁEK FIZYCZNY A ZANIECZYSZCZENIA POWIETRZA - OBSERWACJE U LUDZI}

Wyniki badań prowadzonych wśród zdrowych osób dorosłych często wskazują, że krótkotrwałe narażenie na zanieczyszczenie powietrza w czasie wysiłku fizycznego prowadzi do przejściowego pogorszenia sprawności wentylacyjnej płuc. Wykazano ponadto, że w warunkach podwyższonego poziomu zanieczyszczenia powietrza wysiłek fizyczny odznacza się niższą wydajnością metaboliczną, wyrażającą się zmniejszonym maksymalnym zużyciem tlenu i zwiększeniem stężenia mleczanów w surowicy (24-25). W zakresie sprawności wentylacyjnej do często rejestrowanych zmian należy zmniejszenie natężonej objętości wydechowej pierwszosekundowej $\left(\mathrm{FEV}_{1}\right)$. Rundell i wsp. wykazali istotne statystycznie obniżenie wartości $\mathrm{FEV}_{1}$ w odpowiedzi na 30-minutowy intensywny wysiłek fizyczny w postaci szybkiego biegu w warunkach podwyższonego stężenia $\mathrm{PM}_{1}$ (26). Podobny efekt obserwowano w warunkach eksperymentalnej ekspozycji na spaliny silnika Diesla (27). Co istotne, analogiczne zmiany towarzyszyły biernemu narażeniu na dym tytoniowy przed wysiłkiem - w odpowiedzi na maksymalny wysiłek nastąpiło zmniejszenie wartości $\mathrm{FEV}_{1}$ oraz wzrost stężenia cytokin prozapalnych (TNF- $\alpha$ i IFN- $\gamma$ ) w stosunku do grupy kontrolnej (28). Negatywny wpływ zanieczyszczenia pyłem na wyniki spirometrii zaobserwowano również w innym eksperymencie przeprowadzonym wśród zdrowych ochotników w Barcelonie. Badanie obejmowało cztery scenariusze - 2-godzinny wysiłek lub odpoczynek w miejscach o niskim i wysokim natężeniu ruchu ulicznego. Wykazano, że każdy wzrost stężenia $\mathrm{PM}_{2,5}$ o rozstęp międzykwartylowy związany był $\mathrm{z}$ istotnym zmniejszeniem wartości $\mathrm{FEV}_{1}$ i natężonej pojemności życiowej (FVC). Równocześnie zastosowany protokół umożliwił wykazanie, że wysiłek fizyczny związany był 
In terms of cardiovascular system, among other changes, decreased heart rate variability as a result of exposure to $\mathrm{PM}_{2,5}$ during physical exercises was observed (30). It is worth to mention, that in the cited study the researchers compared effects of exercising in the conditions of low and high level of air pollution. More complex information is given by the studies which study design includes also period of rest. For example, the research conducted in Barcelona showed that, while diastolic blood pressure increased after 2-hours exposure to traffic related air pollution both at rest and during exercises, physical activity limited the negative impact of air pollution on systolic blood pressure (9). Authors of the experiment concluded that, in healthy adults, moderate intermittent physical activity was related to better spirometry results received after exercise than after the same amount of time at rest (31). Large cohort study from Taiwan analysed the impact of physical activity and exposure to $\mathrm{PM}_{2,5}$ on the morphological parameters in two years period of time. Its results demonstrated that physical activity and exposure to $\mathrm{PM}_{2.5}$ are independently and contradictorily connected with systemic inflammation, expressed in lymphocytes level (33).

\section{PHYSICAL ACTIVITY AND AIR POLLUTION - OBSERVATIONS IN ANIMAL EXPERIMENTS}

Research on animals provides further evidence for the complex relationship between the positive biological impact of physical activity and the negative effect of air pollution. Studies frequently indicate that the proinflammatory impact of environmental exposure may be limited by physical activity. In mice regular aerobic exercise limited the increase in proinflammatory cytokines like TNF- $\alpha$ and IL-6, leukocytes and FeNO, caused by long-term exposure to particulate matter (34-35). This is confirmed by the study of SilvaRenno et al. Authors showed that controlled physical exercise in the conditions of exposure to particulate air pollution limited the induced by particulate matter increase in white blood cells count and proinflammatory cytokines IL-1 and TNF- $\alpha$ and at the same time caused increase in anti-inflammatory cytokine IL-10 level in bronchoalveolar lavage (BAL) (32). It has been also proven that the intensity of physical exercise plays important role. Mai et al. showed, that only in the group of mice that were subjected to high-intensity exercises during exposure to $\mathrm{PM}_{2,5}$, the level of extracellular heat-shock proteins (eHSP70) was low. This effect was not observed when the mice were subjected to moderate exercises. Low level of eHSP70 is a marker of antiinflammatory profile (36). z istotnym wzrostem takich parametrów spirometrycznych jak $\mathrm{FEV}_{1}$, wskaźnika Tiffeneau $\left(\mathrm{FEV}_{1} / \mathrm{FVC}\right)$ oraz maksymalnego przepływu środkowowydechowego $\left(\mathrm{MEF}_{25-75}\right)$. Efekt ten, choć osłabiony, był obserwowany również w czasie ćwiczenia w warunkach narażenia na podwyższone stężenia $\mathrm{PM}_{2,5}(8)$. Ta obserwacja unaocznia złożoność relacji między poziomem zanieczyszczenia powietrza a natężeniem wysiłku fizycznego, w odniesieniu do odpowiedzi biologicznej organizmu. Na możliwość ograniczania negatywnych oddziaływań ekspozycji na zanieczyszczenia powietrza przez aktywność fizyczną wskazują również rezultaty badań analizujących długoterminowe efekty. Laeremans i wsp. analizowali wpływ aktywności fizycznej i narażenia ochotników na zanieczyszczenia pyłowe w okresach tygodniowych na wyniki badania spirometrycznego, które wykonywane było na początku i na końcu okresu pomiarowego (29). Chociaż autorzy zaobserwowali pogorszenie funkcji płuc $\mathrm{w}$ zakresie parametrów spirometrycznych $\left(\mathrm{FEV}_{1}, \mathrm{FEV}_{1} / \mathrm{FVC}, \mathrm{MEF}_{25-75}\right) \mathrm{w}$ odpowiedzi na narażenie, to przy niskich stężeniach zanieczyszczeń węglowych $\left(<1 \mu \mathrm{g} / \mathrm{m}^{3}\right)$ występował trend w kierunku poprawy funkcji płuc na każdy wzrost tygodniowej aktywności o 1 równoważnik metaboliczny na godzinę (MET/h).

W zakresie układu krążenia obserwowano między innymi zmniejszoną zmienność rytmu serca w wyniku narażenia na $\mathrm{PM}_{2,5}$ w czasie wysiłku fizycznego (30). Warto zauważyć, że w cytowanym badaniu porównywano efekty wysiłku w warunkach niskiego oraz wysokiego poziomu narażenia na zanieczyszczenia. Pełniejszej informacji dostarczają wyniki badań, które w protokole badawczym uwzględniają również okres odpoczynku. Na przykład badanie przeprowadzone w Barcelonie wykazało, że o ile ciśnienie rozkurczowe wzrastało po 2-godzinnym narażeniu na zanieczyszczenia powietrza emitowane przez transport samochodowy, zarówno w czasie odpoczynku, jak też w przypadku wykonywania w tym czasie ćwiczeń fizycznych, o tyle aktywność fizyczna związana była ze zmniejszeniem negatywnego wpływu zanieczyszczeń powietrza na ciśnienie skurczowe (9). W omawianym eksperymencie stwierdzono, że umiarkowana przerywana aktywność fizyczna wiązała się u zdrowych osób dorosłych z osiągnięciem lepszych wyników spirometrii po wysiłku, niż po takim samym czasie odpoczynku (31). Obszerne badanie kohortowe z Tajwanu analizujące wpływ aktywności fizycznej i narażenia na $\mathrm{PM}_{2,5}$ na parametry morfologiczne w okresie dwóch lat wykazało, że aktywność fizyczna i narażenie na $\mathrm{PM}_{2,5}$ są niezależnie od siebie i przeciwstawnie związane z zapaleniem systemowym, wyrażonym przez stężenie leukocytów (33). 


\section{RECREATIONAL PHYSICAL ACTIVITY AND THE PROBLEM OF AIR POLLUTION}

Explanation of the relations between physical activity and exposure to particulate matter air pollution in the context of biological response is a subject of current research. Several publications document the negative health effects of exposure $(1,5-6,10-12$, 19-20). On the other hand, some authors show slight, but significant positive effects of physical exercises in comparison to lack of physical activity at the same level of exposure $(8-9,31)$. It should be noted that these observations generally relate to young, healthy adults and the results often come from countries with low air pollution levels. In case of older people, evidence for positive effects of recreational physical activity is given among others by a study conducted in three groups - healthy people above 60 years old, patients with chronic obstructive pulmonary disease and people suffering from stable ischemic heart disease. Low-intensity exercise, namely walking in a park for 2 hours, was related with improvement of lung function, expressed in $\mathrm{FEV}_{1}$ and $\mathrm{FVC}$ increase. In all groups this effect was limited or negated, when the walk took place in a proximity to busy street in conditions of high level of ambient particulate matter (37). Studies including representative group in the USA and observation of cohort of students living in Beijing confirmed that the increase in air pollution level discourage people from participating in exercises, what leads to the decrease of general physical activity level (38-40). This situation, despite limiting the exposure by resigning from exercises, may lead to negative health effects due to lack of physical activity. Thus, apart from actions aiming at air quality improvement in cities and countries with significant air pollution problem, information campaigns are needed in order to promote safe and regular physical activity, considering special circumstances of air pollution episodes. For this purpose further studies are needed in order to balance the benefits and risks resulting from recreational physical activity in the conditions of exposure to different air pollution levels. An example of such analysis is study of Tainio et al. Authors assessed that, by $\mathrm{PM}_{2,5}$ concentrations of $100 \mu \mathrm{g} / \mathrm{m}^{3}$, losses outweigh benefits after exercise equal to one and half hour of cycling a day (41).

\section{CURRENT RECOMMENDATIONS ON ACCEPTABLE AIR POLLUTION LEVELS AND PHYSICAL ACTIVITY}

The results of previous studies indicate that in case of long-term exposure there is most likely no safe level of air pollution, below which the nega-

\section{WYSIŁEK FIZYCZNY A ZANIECZYSZCZENIA POWIETRZA - OBSERWACJE W EKSPERYMENTACH ZWIERZĘCYCH}

Badania prowadzone na zwierzętach dostarczają dalszych dowodów na występowanie złożonych zależności pomiędzy korzystnym biologicznie wpływem wysiłku fizycznego a negatywnym oddziaływaniem zanieczyszczeń powietrza. Często wskazuje się na ograniczenie prozapalnego oddziaływania narażenia środowiskowego przez aktywność fizyczną. U myszy regularny aerobowy wysiłek fizyczny wiązał się z ograniczeniem powodowanego przez długotrwałe narażenie na pył zwieszony wzrostu stężenia cytokin prozapalnych, takich jak TNF- $\alpha$ i IL-6, leukocytów i stężenia tlenku azotu w wydychanym powietrzu (34-35). Opisane efekty znajdują potwierdzenie w badaniu Silva-Renno i wsp., które wykazało, że kontrolowany wysiłek fizyczny w warunkach narażenia na pył zawieszony w powietrzu wiąże się z ograniczeniem indukowanego przez pył wzrostu stężenia leukocytów i cytokin prozapalnych IL-1 i TNF- $\alpha$ oraz podwyższeniem stężenia antyzapalnej IL-10 w popłuczynach oskrzelowo-płucnych (BAL) (32). Udowodniono również, że istotne znaczenie ma intensywność wysiłku fizycznego. Mai i wsp. wykazali, że jedynie $\mathrm{w}$ grupie myszy poddawanych intensywnemu wysiłkowi, w czasie narażenia na $\mathrm{PM}_{25}$, zaobserwowano niskie stężenie pozakomórkowych białek szoku termicznego 70 (eHSP70), będące wyrazem profilu antyzapalnego. Efekt ten nie występował u myszy poddawanych umiarkowanemu wysiłkowi (36).

\section{REKREACYJNA AKTYWNOŚĆ FIZYCZNA A PROBLEM ZANIECZYSZCZENIA POWIETRZA}

Wyjaśnienie relacji pomiędzy wysiłkiem fizycznym a narażeniem na zanieczyszczenie powietrza pyłem zawieszonym w kontekście odpowiedzi ustrojowej stanowi przedmiot aktualnych badań. Szereg publikacji dokumentuje negatywne skutki zdrowotne narażenia $(1,5-6,10-$ $12,19-20)$. Z drugiej strony, niektórzy autorzy wskazują na wprawdzie niewielkie, ale korzystne efekty ćwiczeń fizycznych w stosunku do sytuacji braku aktywności fizycznej przy takim samym poziomie narażenia $(8-9,31)$. Należy odnotować, że z reguły te obserwacje dotyczą młodych, zdrowych osób dorosłych, a wyniki badań często pochodzą z regionów charakteryzujących się niskimi poziomami zanieczyszczeń powietrza. W przypadku starszych osób dowodów na korzystny wpływ rekreacyjnej aktywności fizycznej dostarcza między innymi badanie prowadzone w trzech grupach: zdrowych osób powyżej 60 roku życia, chorych na przewlekłą obturacyjną chorobą płuc oraz chorych na stabilną chorobą niedokrwienną serca. Wysiłek o niewielkiej intensywności w postaci 2-godzinego spaceru $\mathrm{w}$ parku wiązał się $\mathrm{z}$ poprawą funkcji płuc, wyrażoną przez wzrost $\mathrm{FEV}_{1}$ oraz FVC. 
tive health effects are no longer observed (42). This is a reason why World Health Organisation (WHO) air quality guidelines are very restrictive (43). Many countries, including European Union states, accept different, most often higher reference values, because more strict WHO guidelines are still difficult to be met. In the EU alone the proportion of urban population exposed to $\mathrm{PM}_{2,5}$ levels exceeding the WHO reference concentrations in 2015 was almost $81 \%$ (3). Apart from mentioned acceptable levels, countries specify individual information and alarm levels. In Poland, a country with one of the highest ambient particulate matter concentrations in the EU, alarm levels are particularly high (3-4).

Recommendations on physical activity result from commonly known positive effects of regular exercises, especially towards respiratory and cardiovascular system (44-45). It is estimated that, in indirect way, lack of physical activity is substantially shaping non-accidental mortality in European population (7). It is therefore an area of large potential for prophylaxis. WHO recommends that people aged 18-64 should maintain at least 150 minutes of moderate or 75 minutes of intensive physical exercises a week (7). Kahlmeier et al. analysed European recommendations and showed that 16 countries, including Poland, did not have national physical activity guidelines (46). Although available data proves the increase of exposure to air pollution during physical exercises, most of recommendations, including WHO guidelines, do not refer to air quality. One of the few examples of practical use of information about current air quality in order to decrease the exposure through proper adjustment of physical activity is the Air Quality Flag Program, supported by the US Environmental Protection Agency (EPA) (47). It is based on pairing specific colours and recommendations with air quality index (AQI) (for its assessment concentrations of $\mathrm{PM}_{2,5}, \mathrm{PM}_{10}, \mathrm{NO}_{2}, \mathrm{SO}_{2}$, $\mathrm{O}_{3}$ and $\mathrm{CO}$ are used). Flags of adequate colour are placed by schools in order to communicate the current health risk in simple and effective way (48). In Poland, similar recommendations are given by the Chief Inspectorate of Environmental Protection (Gtówny Inspektorat Ochrony Środowiska - GIOŚ). Based on Polish air quality index, different from the American (Polish index considers concentrations of $\mathrm{PM}_{2,5}, \mathrm{PM}_{10}, \mathrm{NO}_{2}, \mathrm{SO}_{2}, \mathrm{O}_{3}, \mathrm{CO}$ and $\mathrm{C}_{6} \mathrm{H}_{6}$ ), descriptive categories marked with different colours and health information are given (49). EPA and GIOŚ recommendations are presented in Table I.
We wszystkich grupach efekt ten był zmniejszony lub zniesiony, gdy spacer miał miejsce przy ruchliwej ulicy w warunkach podwyższonych stężeń pyłu zawieszonego (37). Badania obejmujące reprezentatywną grupę w USA oraz obserwacja kohorty studentów mieszkających w Pekinie potwierdziły, że wzrost stężenia zanieczyszczeń powietrza zniechęca do podejmowania ćwiczeń, co prowadzi do zmniejszenia ogólnego poziomu aktywności (38-40). Sytuacja taka, pomimo ograniczenia narażenia przez rezygnację z ćwiczeń, może wiązać się z negatywnymi skutkami dla zdrowia, wynikającymi z braku aktywności fizycznej. Z tego powodu, poza działaniami zmierzającymi do poprawy jakości powietrza w miastach i krajach o znacznym poziomie zanieczyszczeń, potrzebne są działania informacyjne promujące bezpieczną i regularną aktywność fizyczną, z uwzględnieniem szczególnych okoliczności dotyczących epizodów występowania wysokich stężeń zanieczyszczeń. W tym celu niezbędne są badania, zmierzające do wyważenia korzyści i ryzyka wynikających z uprawiania rekreacyjnej aktywności fizycznej przy jednoczesnym narażeniu na różne stężenia zanieczyszczeń. Przykładem takiej analizy jest praca Tainio i wsp., którzy oszacowali, że w przypadku stężeń $\mathrm{PM}_{2,5}$ przekraczających $100 \mu \mathrm{g} / \mathrm{m}^{3}$ bilans strat przekracza korzyści przy wysiłku odpowiadającym półtoragodzinnej jeździe na rowerze dziennie (41).

\section{AKTUALNE REKOMENDACJE DOTYCZĄCE DOPUSZCZALNYCH POZIOMÓW ZANIECZYSZCZEŃ I AKTYWNOŚCI FIZYCZNEJ}

Wyniki dotychczasowych badań wskazują, że w warunkach długotrwałych narażeń najprawdopodobniej nie istnieje bezpieczny poziom zanieczyszczeń powietrza, poniżej którego negatywne skutki zdrowotne nie są już obserwowane (42). Z tego powodu rekomendacje przyjęte przez Światową Organizację Zdrowia (World Health Organization -WHO) dotyczące zalecanych maksymalnych poziomów zanieczyszczeń są bardzo restrykcyjne (43). Wiele państw, w tym kraje Unii Europejskiej, przyjmuje inne, z reguły wyższe wartości referencyjne, gdyż bardziej restrykcyjne zalecenia WHO w dużej mierze wciąż są trudne do spełnienia. W samej UE odsetek populacji miejskiej narażonej w roku 2015 na stężenia $\mathrm{PM}_{2,5}$ przekraczające wartości zalecane w wytycznych WHO wynosił prawie $81 \%$ (3). Poza wymienionymi poziomami dopuszczalnymi, indywidualnie przez poszczególne kraje określane są również poziomy informowania i poziomy alarmowe. W Polsce, która jest jednym z krajów o najwyższych stężeniach pyłu zawieszonego w Unii Europejskiej, poziomy alarmowe są szczególnie wysokie (3-4). 
Table I. EPA and GIOŚ recommendations on outdoor physical activity for risk groups and healthy people.*

Tabela I. Zalecenia EPA oraz GIOŚ dotyczące aktywności fizycznej na zewnątrz pomieszczeń z podziałem na osoby zdrowe i osoby z grup ryzka**

\begin{tabular}{|c|c|c|c|c|c|}
\hline \multicolumn{3}{|c|}{ EPA } & \multicolumn{3}{|c|}{ GIOŚ } \\
\hline Colour & \multicolumn{2}{|c|}{$\begin{array}{l}\text { Recommendation on outdoor } \\
\text { activity }\end{array}$} & Category & \multicolumn{2}{|c|}{ Recommendation on outdoor activity } \\
\hline \multirow{2}{*}{ Green } & \multirow{2}{*}{ All } & \multirow{2}{*}{$\begin{array}{c}\text { Good day for outdoor } \\
\text { exercise }\end{array}$} & Very good & \multirow{2}{*}{ All } & \multirow{2}{*}{ No restrictions } \\
\hline & & & Good & & \\
\hline Yellow & All & $\begin{array}{c}\text { Good day for outdoor } \\
\text { exercise } * *\end{array}$ & Moderate & All & $\begin{array}{l}\text { Moderate conditions } \\
\text { for exercising outdoors }\end{array}$ \\
\hline \multirow[b]{2}{*}{ Orange } & Healthy & $\begin{array}{c}\text { It is } \mathrm{OK} \text { to exercise } \\
\text { outdoors }\end{array}$ & \multirow[b]{2}{*}{ Sufficient } & \multirow[b]{2}{*}{ All } & \multirow{2}{*}{$\begin{array}{l}\text { Consider reduction } \\
\text { or shortening of the } \\
\text { exertion }\end{array}$} \\
\hline & $\begin{array}{l}\text { Risk } \\
\text { groups } \\
* * *\end{array}$ & $\begin{array}{l}\text { Reduce prolonged or } \\
\text { heavy exertion, take } \\
\text { more breaks }\end{array}$ & & & \\
\hline \multirow[b]{2}{*}{ Red } & Healthy & $\begin{array}{l}\text { Reduce prolonged or } \\
\text { heavy exertion, take } \\
\text { more breaks }\end{array}$ & \multirow[b]{2}{*}{ Bad } & Healthy & $\begin{array}{l}\text { Limit to a minimum all } \\
\text { physical activity }\end{array}$ \\
\hline & $\begin{array}{l}\text { Risk } \\
\text { groups }\end{array}$ & $\begin{array}{l}\text { Avoid prolonged or } \\
\text { heavy exertion, take } \\
\text { more breaks, move } \\
\text { activities indoors or } \\
\text { reschedule to a time } \\
\text { when the air quality } \\
\text { is better }\end{array}$ & & $\begin{array}{l}\text { Risk } \\
\text { groups }\end{array}$ & $\begin{array}{l}\text { Reduce time spent } \\
\text { outdoors }\end{array}$ \\
\hline \multirow[t]{2}{*}{ Purple } & Healthy & $\begin{array}{l}\text { Avoid prolonged or } \\
\text { heavy exertion, take } \\
\text { more breaks, move } \\
\text { activities indoors or } \\
\text { reschedule to a time } \\
\text { when the air quality } \\
\text { is better }\end{array}$ & \multirow[t]{2}{*}{ Very bad } & Healthy & $\begin{array}{l}\text { All activietes outdoors } \\
\text { are discouraged, limit } \\
\text { to a minimum time } \\
\text { spent outdoors }\end{array}$ \\
\hline & $\begin{array}{l}\text { Risk } \\
\text { groups }\end{array}$ & $\begin{array}{l}\text { Avoid all physical } \\
\text { activity, move } \\
\text { activities indoors or } \\
\text { reschedule to a time } \\
\text { when the air quality } \\
\text { is better }\end{array}$ & & $\begin{array}{c}\text { Risk } \\
\text { Groups }\end{array}$ & $\begin{array}{c}\text { Absolutely avoid } \\
\text { spending time outdoors }\end{array}$ \\
\hline
\end{tabular}

* Based on EPA (https://airnow.gov) and GIOŚ (https://powietrze.gios.gov.pl) recommendations. In order to simplify the table, data is presented in parallel, although Polish and American indxes are not equal. Therefore categories e.g. "yellow” EPA and „moderate” GIOŚ do not show the same level of exposure. ** In case of particularly sensitive individuals limitation of activities is recommended. *** Risk groups: children, pregnant women, elderly and those with heart or lung disease.

\section{CONCLUSIONS}

Exposure to particulate matter air pollution is connected with negative health effects, particularly from respiratory and circulatory systems. Recreational physical activity in the conditions of high particulate matter concentrations, due to among others intensified ventilation, leads to the increase in the risk of negative effects of air pollution. Nevertheless, effects of interactions between the exposure to particles and the impact of physical exercises observed in experimental con-
Zalecenia dotyczące aktywności fizycznej wynikają z powszechnie znanych pozytywnych efektów regularnego wysiłku fizycznego, szczególnie w odniesieniu do funkcjonowania układu oddechowego i krążenia (4445). Szacuje się, że w sposób pośredni brak aktywności fizycznej w znacznym stopniu kształtuje niewypadkową przyczynę umieralności w populacji europejskiej (7). Jest to zatem obszar o dużym potencjale profilaktycznym i z tego powodu WHO zaleca, aby osoby w wieku 18-64 lat utrzymywały co najmniej 150 minut umiarkowanego lub 75 minut intensywnego wysiłku fizycznego w tygodniu (7). 
ditions are ambiguous. Air pollution may limit positive health effects of exercises, also in healthy young adults, resulting in deterioration of lung function expressed in spirometry parameters. On the contrary, it has been shown that in healthy people physical activity may inhibit proinflammatory impact of particulate matter on the airways. Complete understanding of the relations between the physical activity and the exposure to air pollution requires further studies, conducted both in healthy people and in risk groups. New observations referring to the local environmental conditions and recreational physical activity are needed, taking into consideration the variable nature of air pollution. It will allow developing recreational physical activity guidelines that would refer to current and adequate for each region type and level of air pollution, proper risk communication and promotion of safe ways of active recreation.

\section{REFERENCES}

1. Thurston GD, Kipen H, Anneso-Maesano I, et al. A joint ERS/ATS policy statement: what constitutes an adverse health effect of air pollution? An analytical framework. Eur Respir J 2017; 49(1): 1600419.

2. Cichowicz R, Wielgosiński G, Fetter W. Dispersion of atmospheric air pollution in summer and winter season. Environ Monit Assess 2017; 189(12): 605.

3. European Environment Agency. Air Quality in Europe - 2018 Report. Publications Office of the European Union, Luxembourg 2018: 26-34, 56-61.

4. Juda-Rezler K, Toczko B. Pyły Drobne w Atmosferze. Kompendium Wiedzy o Zanieczyszczeniu Powietrza Pyłem Zawieszonym w Polsce. Biblioteka Monitoringu Środowiska, Warszawa 2016: 97-105,

5. Kim KH, Kabir E, Kabir S. A review on the human health impact of airborne particulate matter. Environ. Int 2015; 74: 136-143.

6. Kowalska M, Kocot K. Short-term exposure to ambient fine particulate matter $\left(\mathrm{PM}_{2,5}\right.$ and $\left.\mathrm{PM}_{10}\right)$ and the risk of heart rhythm abnormalities and stroke. Postepy Hig Med Dosw 2016; 70(0): 1017-1025.

7. World Health Organization. Global Recommendations on Physical Activity for Health. World Health Organization, Geneva 2010: 7-8.

8. Matt F, Cole-Hunter T, Donaire-Gonzalez D, et al. Acute respiratory response to traffic-related air pollution during physical activity performance. Environ Int 2016; 97: 45-55.

9. Kubesch NJ, De Nazelle A, Guerra S,et al. Arterial blood pressure responses to short term exposure to low and high traffic related air pollution with and without moderate physical activity. Eur J Prev Cardiol 2015; 22(5): 548-57.

10. Rundell KW. Effect of air pollution on athlete health and performance. Br J Sports Med 2012; 46(6): 407-12.
Kahlmeier i wsp. dokonując analizy istniejących w krajach europejskich rekomendacji wskazali, że w przypadku 16 krajów, w tym również Polski, nie opracowano krajowych rekomendacji dotyczących aktywności fizycznej (46). Trzeba jednakże zauważyć, że pomimo danych dowodzących zwiększonego narażenia na zanieczyszczenia powietrza w trakcie wysiłku fizycznego, większość dostępnych zaleceń, w tym rekomendacje WHO, nie odnoszą się do jakości powietrza. Jednym z niewielu przykładów praktycznego wykorzystania informacji o bieżącej jakości powietrza w celu zmniejszenia narażenia poprzez odpowiednie dostosowanie stopnia aktywności fizycznej jest projekt Air Quality Flag Program wspierany przez amerykańską Agencję Ochrony Środowiska (Environmental Protection Agency - EPA) (47). Polega on na przypisaniu odpowiednim wartościom indeksu jakości powietrza (AQI) (uwzględniającego stężenia pyłu $\mathrm{PM}_{2,5}$ i $\left.\mathrm{PM}_{10}, \mathrm{NO}_{2}, \mathrm{SO}_{2}, \mathrm{O}_{3} \mathrm{i} \mathrm{CO}\right)$ odpowiednich kolorów i towarzyszących im zaleceń. Flagi odpowiedniego koloru umieszczane są przy szkołach, aby w prosty i skuteczny sposób komunikować istniejące ryzyko (48). Polskim odpowiednikiem tych zaleceń są informacje zdrowotne Głównego Inspektoratu Ochrony Środowiska (GIOŚ). Na podstawie polskiego indeksu jakości powietrza, odmiennego od amerykańskiego (polski indeks uwzględnia stężenia pyłu $\mathrm{PM}_{2,5}$ i $\mathrm{PM}_{10}, \mathrm{NO}_{2}, \mathrm{SO}_{2}, \mathrm{O}_{3}, \mathrm{CO} \mathrm{i} \mathrm{C}_{6} \mathrm{H}_{6}$ ) wyznaczono kategorie opisowe oznaczone kolorami oraz odpowiadające im informacje zdrowotne (49). Zalecenia EPA i GIOŚ przedstawiono w Tabeli I.

\section{WNIOSKI}

Narażenie na zanieczyszczenie powietrza pyłem zawieszonym wiąże się z niekorzystnymi skutkami zdrowotnymi, szczególnie w zakresie układu oddechowego i krążenia. Rekreacyjna aktywność fizyczna w warunkach występowania podwyższonych stężeń pyłu, między innymi poprzez zwiększoną wentylację, przyczynia się do zwiększonego narażenia na negatywne skutki oddziaływania zanieczyszczeń powietrza. Mimo to, obserwowane w warunkach eksperymentalnych efekty interakcji pomiędzy narażeniem na pył a wpływem wysiłku fizycznego są niejednoznaczne. $Z$ jednej strony zanieczyszczenie powietrza może prowadzić do ograniczenia pozytywnych oddziaływań wysiłku fizycznego na zdrowie człowieka, również u zdrowych, młodych osób dorosłych, prowadząc do pogorszenia czynności płuc wyrażonej w parametrach spirometrycznych. $Z$ drugiej strony wskazuje się na fakt, że wysiłek fizyczny może u zdrowych osób ograniczać prozapalny wpływ pyłu zawieszonego na drogi oddechowe. Pełne poznanie relacji pomiędzy wysiłkiem fizycznym a narażeniem na zanieczyszczenie powietrza wymaga dalszych badań, prowadzonych zarówno wśród zdrowych osób, jak i w grupach ry- 
11. Giles LV, Koehle MS. The health effects of exercising in air pollution. Sports Med 2014; 44(2): 223-49.

12. Riediker M, Franc Y, Bochud M, et al. Exposure to fine particulate matter leads to rapid Heart Rate Variability changes. Front Environ Sci 2018; 6.

13. Zhang J, Zhu T, Kipen H, et al. Cardiorespiratory biomarker responses in healthy young adults to drastic air quality changes surrounding the 2008 Beijing Olympics. Res Rep Health Eff Inst 2013; 174: 5-174.

14. Annesi-Maesano I, Dinh-Xuan AT. Is exhaled nitric oxide a marker of air pollution effect? Eur Respir J 2016; 47(5): 1304-6.

15. Shi J, Chen R, Yang C, et al. Association between fine particulate matter chemical constituents and airway inflammation: A panel study among healthy adults in China. Environ Res 2016; 150: 264-8.

16. Carlsen HK, Boman P, Björ B, et al. Coarse fraction particle matter and exhaled nitric oxide in non-asthmatic children. Int J Environ Res Public Health 2016; 13(6).

17. Chen R, Qiao L, Li H, et al. Fine particulate matter constituents, nitric oxide synthase DNA methylation and exhaled nitric oxide. Environ Sci Technol 2015; 49(19): 11859-65.

18. Cao J, Xu H, Xu Q, et al. Fine particulate matter constituents and cardiopulmonary mortality in a heavily polluted Chinese city. Environ Health Perspect 2012; 120(3): 373-378.

19. Liang R, Zhang B, Zhao X, et al. Effect of exposure to PM2.5 on blood pressure: a systematic review and meta-analysis. J Hypertens 2014; 32(11): 2130-40.

20. Tsai DH, Riediker M, Wuerzner G, et al. Short-term increase in particulate matter blunts nocturnal blood pressure dipping and daytime urinary sodium excretion. Hypertension 2012; 60(4): 1061-9.

21. Yoda Y, Takagi H, Wakamatsu J, et al. Acute effects of air pollutants on pulmonary function among students: a panel study in an isolated island. Environ Health Prev Med 2017; 22(1): 33.

22. Soppa VJ, Schins RPF, Hennig F, et al. Arterial blood pressure responses to short-term exposure to fine and ultrafine particles from indoor sources - A randomized sham-controlled exposure study of healthy volunteers. Environ Res 2017; 158: 225-232.

23. Oravisjarvi K, Pietikainen M, Ruuskanen J, et al. Effects of physical activity on the deposition of traffic-related particles into the human lungs in silico. Sci Total Environ 2011; 409(21): 4511-8.

24. Kargarfard M, Poursafa P, Rezanejad S, et al. Effects of exercise in polluted air on the aerobic power, serum lactate level and cell blood count of active individuals. Int J Prev Med 2011; 2(3): 145-50.

25. Kargarfard M, Shariat A, Shaw BS, et al. Effects of polluted air on cardiovascular and hematological parameters after progressive maximal aerobic exercise. Lung 2015; 193(2): 275-81.

26. Rundell KW, Slee JB, Caviston R, et al.. Decreased lung function after inhalation of ultrafine and fine particulate matter during exercise is related to decreased total nitrate in exhaled breath condensate. Inhal Toxicol 2008; 20: $1-9$. zyka. Uwzględniając zmienną charakterystykę zanieczyszczeń powietrza niezbędne są nowe obserwacje odnoszące się do lokalnych warunków środowiskowych i swobodnej, rekreacyjnej aktywności fizycznej. Pozwoli to na wypracowanie rekomendacji odnośnie rekreacyjnej aktywności fizycznej, uwzględniających aktualny, właściwy dla danego regionu typ i poziom zanieczyszczenia powietrza, właściwe komunikowanie ryzyka i promowanie bezpiecznych form rekreacji związanej z wysiłkiem fizycznym.

27. Giles LV, Carlsten C, Koehle MS. The effect of pre-exercise diesel exhaust exposure on cycling performance and cardiorespiratory variables. Inhal Toxicol 2012; 24(12): 783-9.

28. Flouris AD, Metsios GS, Carrill AE, et al. Respiratory and immune response to maximal physical exertion following exposure to secondhand smoke in healthy adults. PLoS ONE $2012 ; 7(2)$ : e31880.

29. Laeremans M, Dons E, Avila-Palencia I, et al. Black carbon reduces the beneficial effect of physical activity on lung function. Med Sci Sports Exerc 2018; 50(9): 1875-1881.

30. Weichenthal S, Hatzopoulou M, Goldberg MS. Exposure to traffic-related air pollution during physical activity and acute changes in blood pressure, autonomic and micro-vascular function in women: a cross-over study. Part Fibre Toxicol 2014; 11: 70.

31. Kubesch NJ, De Nazelle A, Westerdahl D, et al. Respiratory and inflammatory responses to short-term exposure to traffic-related air pollution with and without moderate physical activity. Occup Environ Med 2015; 72(4): 284-93.

32. Zhang Z, Hoek G, Chang L, et al. Particulate matter air pollution, physical activity and systemic inflammation in Taiwanese adults. Int J Hyg Environ Health 2018; 221(1): 41-47.

33. Vieira RP, Toledo AC, Silva LB, et al. Anti-inflammatory effects of aerobic exercise in mice exposed to air pollution. Med Sci Sports Exerc 2012; 44(7): 1227-34.

34. Fashi M, Agha Alinejad H, Asilian Mahabadi H. The effect of aerobic exercise in ambient particulate matter on lung tissue inflammation and lung cancer. Iran J Cancer Prev 2015; 8(3): e2333.

35. Silva-Renno A, Baldivia GC, Oliveira-Junior MC, et al. Exercise performed concomitantly with particulate matter exposure inhibits lung injury. Int J Sports Med 2018; 39(2): 133-140.

36. Mai AS, dos Santos AB, Beber LCC, et al. Exercise training under exposure to low levels of fine particulate matter: effects on heart oxidative stress and extra-to-intracellular HSP70 ratio. Oxid Med Cell Longev 2017;2017:9067875.

37. Sinharay R, Gong J, Barratt B, et al. Respiratory and cardiovascular responses to walking down a traffic-polluted road compared with walking in a traffic-free area in participants aged 60 years and older with chronic lung or heart disease and age-matched healthy controls: a randomised, crossover study. Lancet 2018;391(10118):339-349. 
38. Roberts JD, Voss JD, Knight B. The association of ambient air pollution and physical inactivity in the United States. PLoS ONE 2014; 9(3): e90143.

39. Yu H, Yu M, Gordon SP, Zhang R. The association between ambient fine particulate air pollution and physical activity: a cohort study of university students living in Beijing. Int J Behav Nutr Phys Act 2017; 14(1): 136.

40. An R, Yu H. Impact of ambient fine particulate matter air pollution on health behaviors: a longitudinal study of university students in Beijing, China. Public Health 2018 Mar 19. pii: S0033-3506(18)30055-6. doi: 10.1016/j.puhe.2018.02.007. (Epub ahead of print).

41. Tainio M, De Nazelle AJ, Götschi T, i in. Can air pollution negate the health benefits of cycling and walking? Prev Med 2016; 87: 233-236.

42. Barnett AG. It's safe to say there is no safe level of air pollution. Aust N Z J Public Health 2014; 38(5): 407-8.

43. World Health Organization Regional Office for Europe. Air Quality Guidelines Global Update 2005: Particulate Matter, Ozone, Nitrogen Dioxide, and Sulfur Dioxide. World Health Organization Regional Office for Europe, Copenhagen 2006: 173-188.

44. Booth FW, Roberts CK, Laye MJ. Lack of exercise is a major cause of chronic diseases. Compr Physiol 2012; 2(2): 1143-1211.

45. Fuertes E, Carsin AE, Antó JM, et al. Leisure-time vigorous physical activity is associated with better lung function: the prospective ECRHS study. Thorax 2018; 73(4): 376-384.

46. Kahlmeier S, Wijnhoven TMA, Alpiger P, et al. Na- tional physical activity recommendations: systematic overview and analysis of the situation in European countries. BMC Public Health 2015; 15: 133.

47. Environmental Protection Agency, Air Quality Flag Program https://www.airnow.gov/index.cfm?action=flag_program.index (26.02.2019).

48. Shendell DG, Rawling MM, Foster C, et al. The outdoor air quality flag program in central California: a school-based educational intervention to potentially help reduce children's exposure to environmental asthma triggers. J Environ Health 2007; 70(3): 28-31.

49. Główny Inspektorat Ochrony Środowiska, Informacje Zdrowotne - Indeks Jakości Powietrza. http://powietrze.gios.gov.pl/pjp/content/health informations $(15.05 .2019)$

Received: 6.03.2019

Accepted for publication: 3.06.2019

Otrzymano: 6.03.2019 r.

Zaakceptowano do publikacji: 3.06.2019 r.

\section{Adres do korespondencji: \\ Address for correspondence: \\ Krzysztof Kocot}

ul. Graniczna 1A

42-470 Siewierz

tel. 602782323

kjkocot@gmail.com 